S.A. Naida, Y.O. Onykienko, O.I. Drozdenko, O.I. Smolenska, V.S. Baran, N.O. Iakunina

\title{
ANALYSIS OF THE INFLUENCE OF LOAD INDUCTANCE ON NONLINEAR DISTORTIONS OF A CLASS D AMPLIFIER CAUSED BY «DEAD TIME»
}

Goal. Analysis of the effect of load inductance at the output of the class D amplifier for different values of the duration of «dead time» and assessment of the adequacy of existing mathematical models for calculating the THD at the output of the amplifier depending on the duration of "dead time». Methodology. The study of the effect of «dead time» on the THD was performed using a computer model of the half-bridge converter board EPC9035 from Efficient Power Conversion. This board contains GaN transistors EPC2022 eGaN®, the corresponding control driver and other necessary elements for operation. The use of GaN transistors has made it possible to investigate the operation in a wide range of frequent switching, both to control the motor and to amplify the audio signal. Results. It is established that the value of load inductance affects the level of nonlinear distortions caused by «dead time». At inductance values that provide a constant sign of the output current, a difference arises between the duration of the input and output pulses, which increases the THD. At inductance values, when the choke current changes sign during a pulse, there is no error between the duration of the input and output pulses. Changing the inductance changes the relationship between the error signal and the non-error signal. THD changes accordingly. At high conversion frequencies, the voltage spikes caused by the choke current through the built-in diodes during the dead time are partially compensated by overcharging the output capacitance of the transistors, which also reduces harmonic distortion. Originality. For the first time, the value of the THD at the outlets in the fallowness of the different indices of the inductance of the choke and the theoretical calculation of the value in the results of the computer model was obtained. Practical significance. The dependence of the THD values on the inductance of the choke for converters with a switching frequency range from $1 \mathrm{kHz}$ to $400 \mathrm{kHz}$, which allows them to be used both to control the motor and to amplify the audio signal. References 10, tables 2, figures 8.

Key words: GaN transistors, class D amplifier, nonlinear distortion, dead time, THD.

В роботі досліджено вплив індуктивності навантаження підсилювача класу D на значення коефіиієнту гармонічних спотворень (КГС) на виході для різних значень тривалості «мертвого часу» або вимкненого стану вихідних транзисторів. Очінена адекватність існуючих математичних моделей для розрахунку КГС на виході підсилювача в залежності від тривалості «мертвого часу». Наведено результати комп'ютерного моделювання підсилювача класу D та досліджено значення КГС на виході в залежності від різних номіналів індуктивності вихідного дроселя. Виконано порівняння теоретично обчислених значень з результатами комп'ютерного моделювання. В результаті дослідження встановлено, щзо КГС, спричинений наявністю «мертвого часу» залежить від індуктивності навантаження. Отриманий у результаті моделювання КГС співпадає з розрахованим за формулою тільки для певних значень індуктивності навантаження. В моделі використано GaN транзистори, щьо дозволило дослідити роботу підсилювача у широкому діапазоні частот перемикання. Бібл. 10, табл. 2, рис. 8.

Ключові слова: GaN транзистори, підсилювачі класу D, нелінійні спотворення, «мертвий час», коефіцієнт гармонічних спотворень.

В работе исследовано влияние индуктивности нагрузки усилителя класса D на значение коэффициента гармонических искажений (КГИ) на выходе для различных значений продолжстельности «мертвого времени» или выключенного состояния выходных транзисторов. Оиенена адекватность существующих математических моделей для расчета КГИ на выходе усилителя в зависимости от продолжительности «мертвого времени». Приведены результать компьютерного моделирования усилителя класса D и исследованы значение КГИ на выходе в зависимости от различных номиналов индуктивности дросселя. Выполнено сравнение теоретически вычисленных значений с результатами компьютерного моделирования. В результате исследования установлено, что КГИ, вызванный наличием «мертвого времени» зависит от индуктивности нагрузки. Полученный в результате моделирования КГИ совпадает с рассчитанным по формуле только для определенных значений индуктивности нагрузки. В модели использованы GaN транзисторы, что позволило исследовать работу усилителя в широком диапазоне частот переключения. Библ. 10, табл. 2, рис. 8.

Ключевые слова: GaN транзисторы, усилители класса D, нелинейные искажения, мертвое время, коэффициент гармонических искажений.

Introduction. Class D amplifiers are widely used in electric drive, audio equipment and other areas where it is necessary to amplify the input signal with maximum efficiency and minimum distortion. The key mode of operation provides efficiency theoretically up to $100 \%$, and the class D amplifiers themselves are small in size and weight compared to linear amplifiers. The disadvantage of the key mode is electromagnetic interference. Class D amplifiers, as well as other types of amplifiers, are also characterized by nonlinear distortion of the amplified signal. One type of nonlinear distortion is the distortion caused by the so-called «dead time» - the time interval during which the output transistors must be switched off to avoid through currents. Nonlinear distortions of the output signal due to «dead time» are often ignored due to their relatively small values. However, when amplifying the sound signal, such distortions are clearly visible to the ear and significantly reduce the quality of perception of phonograms. Also distortions are undesirable for the output voltage for converters that work as part of power grids.

Studies of the effect of «dead time» on the level of nonlinear distortion at the output of the class D amplifier are sufficiently described in the literature. The analysis of 
distortions caused by «dead time» is described in [1], where the differences between the shapes of input and output signals for different types of modulation are analyzed. The result is the calculated signal spectra at the output for the specified values of «dead time». In [2] the output signal is presented as an input PWM signal with the addition of «dead time» intervals, analytical expressions for calculating the values of the harmonics of the output signal are given.

In [3] the mechanisms of creation of nonlinear distortions caused by «dead time» for the voltage converter are considered. The influence of parasitic output capacitances of transistors and current pulsations of output choke current on the level of distortions is analyzed, the method of their compensation is offered. However, no appropriate methodology is given for calculating the THD. An experimental study of the factors influencing the THD of a class $\mathrm{D}$ amplifier on $\mathrm{GaN} / \mathrm{SiC}$ transistors was performed in [4]. The growth of THD with the increase of «dead time» for active load is established. In [5], a study of the dependence of THD on the load current for different values of «dead time» was performed, and it was shown that the main contribution is made by odd harmonics.

Thorough studies of the influence of the duration of the «dead time» on the THD were performed by Chierchie et al. in [6-8]. Theoretical calculations are given, computer modelling and experimental researches of dependence of THD on value of «dead time» are carried out, practical recommendations on a choice of its duration are given.

However, in the above-mentioned works, the effect of the value of the load inductance on the THD is not evaluated, although the current through the output choke is considered as one of the factors of nonlinear distortion.

Thus, it is expedient to investigate the dependence of the processes of formation of nonlinear distortions at the output of the amplifier during the interval of «dead time» on the inductance of the load.

The goal of the work is to analyze the effect of class D amplifier load inductance on THD caused by the presence of «dead time» and assess the adequacy of existing mathematical models for calculating THD at the amplifier output for different values of «dead time».

To achieve this goal it was necessary to solve the following tasks:

- to analyze with the help of a computer model the value of THD at the output of the class D amplifier depending on the different values of the inductance of the choke for active-inductive load;

- to compare the theoretically calculated THD with the results of computer simulation;

- to explain the results obtained and identify the need for and further ways of conducting research.

Description of the computer model. The study of the effect of «dead time» on the THD was performed using a computer model of the half-bridge converter board EPC9035 of Efficient Power Conversion. This board contains GaN transistors EPC2022 eGaN ${ }^{\circledR}$, the corresponding control driver and other necessary elements for operation. The use of $\mathrm{GaN}$ transistors has made it possible to investigate the operation in a wide range of frequent switching, both to control the electric motor and to amplify the audio signal. The main parameters of the PWM signal in the simulation are given in Table 1.

Table 1 PWM signal parameters

\begin{tabular}{|l|c|}
\hline Switching frequencies & $1 \mathrm{kHz}, 2 \mathrm{kHz}, 100 \mathrm{kHz}, 400 \mathrm{kHz}$ \\
\hline Signal frequencies & $50 \mathrm{~Hz}$ \\
\hline Depth of modulation & 0.6 \\
\hline
\end{tabular}

For computer simulation, a modified model of a half-bridge transducer on GaN transistors was used, which is described in [9]. The peculiarity of this model is that the driver chip of the output transistors LM5113 is replaced by virtual switches $\mathrm{S} 1, \mathrm{~S} 2$, and control voltage sources are replaced by transistors V4, V5. The existing model of the LM5113 chip does not provide accurate reproduction of processes over time, as described in [10], and in addition, the use of switches and voltage sources simplifies the model and reduces the simulation time. In the proposed model, the power supply is represented as bipolar for symmetric amplification of the sinusoidal signal.

The computer model of the amplifier on $\mathrm{GaN}$ transistors is shown in Fig. 1. Element U1 is a pulsewidth modulator with a built-in sawtooth voltage generator. Logic elements U2 and U3 are input buffers. Element U2 also inverts the input signal. Logic elements U4 and U5 are buffers of «dead time» circuit formation. The $R C$ circuit $\mathrm{R} 1, \mathrm{C} 1$ and the diode $\mathrm{D} 1$ form the switchon delay time («dead time») of the transistor $\mathrm{Q} 1$, the $R C$ circuit R2, C2 and the diode D2 form the switch-on delay time of the transistor Q2. At high frequencies, the conversion of the $R C$ circuit is the only way to form a «dead time», when its duration is tens of nanoseconds or less. At sufficiently low conversion frequencies, the formation of dead time is possible by digital methods [3].

Switches S1, S2 are used to generate control voltages of transistors Q1, Q2. When the switch S1 is closed, the voltage of the source V4 is applied between the source and the gate of the transistor Q1. The charge current of the input capacitor of the transistor Q1 is limited by the internal resistance of the switch S1. After opening this switch, the discharge of the input capacitor occurs through the resistor R3. Similar processes occur when controlling the transistor Q2. The load of the amplifier is the choke L1 and resistor R8. Components for modelling losses on the printed circuit board are resistors $\mathrm{R} 1, \mathrm{R} 10$. The decoupling capacitor $\mathrm{C} 3$ is shown in the diagram with parasitic parameters: choke L2 (inductance of terminals), and resistor R10 (internal resistance). The parasitic parameters of the supply wires are represented by chokes L3, L4 and resistors R11, R12. The $12 \mathrm{~V}$ power supply is split in half to speed up the simulation process. The point of connection of the sources is connected to the «ground», which made it possible to abandon the use in the circuit of a capacitor divider, which is necessary for the operation of a half-bridge converter when powered by a unipolar source. 


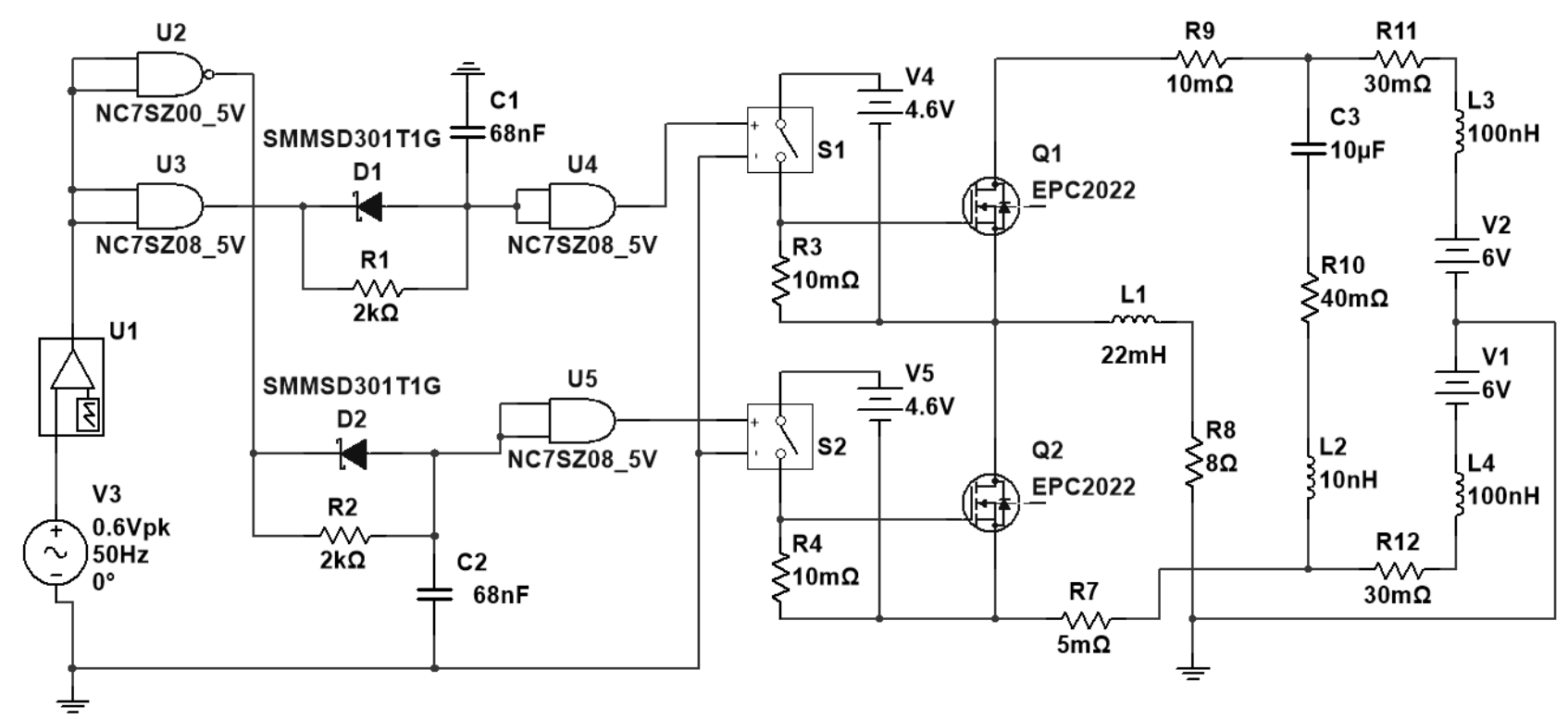

Fig. 1. Computer model of a half-bridge transducer for estimating the effect of «dead time» duration on THD

Problem description. Figure 2 illustrates the process of creating nonlinear distortions due to the introduction of «dead time». The input PWM pulses $U_{\text {in }}(t)$ are indicated by a line with triangles, the pulses at the output of the amplifier $U_{0}(t)$ - by a solid line, the output current $I_{0}(t)$ - by a dotted line , «dead time» is shaded. As can be seen from Fig. 2, the duration of the input and output pulses do not match when the sign of the output current is constant. In this case, at the output of the amplifier there are nonlinear distortions of the amplified signal, regardless of the method of implementation of the PWM. The reason is that during both «dead time» intervals the diode of only one of the transistors operates and provides current flow through the choke in the «dead time» interval, delaying the change of the signal at the output when the input signal has already changed the sign.

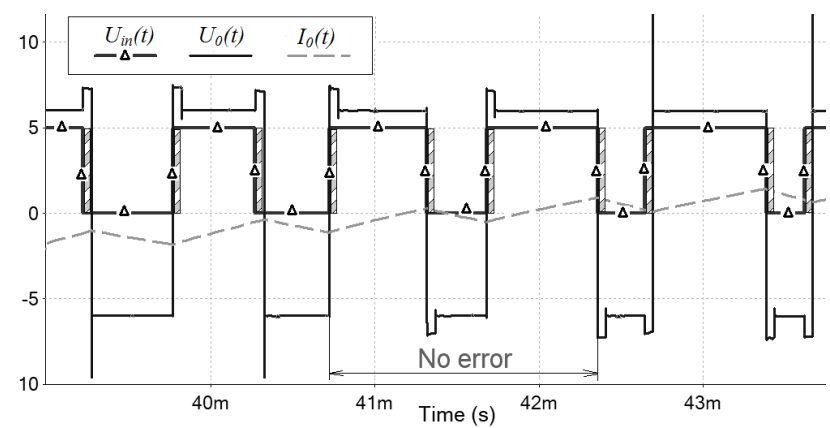

Fig. 2. Illustration of the process of creating nonlinear distortions due to the introduction of «dead time»

If the sign of the output current changes during the pulse duration, the current through the choke at different intervals of «dead time» flows through the diodes of different transistors. The duration of the input and output pulses are the same, and no distortion occurs. This interval is indicated in Fig. 2 as «No error». Thus, at certain values of inductance at the output of the amplifier and the depth of modulation, the delay in changing the sign of the output voltage disappears, and therefore the total value of the THD decreases. Therefore, it is advisable to investigate the effect of choke inductance at the output of the amplifier on the THD, taking into account that the load inductance, in particular class D sound amplifiers, can have a wide range of values.

Description of the mathematical model of the spectrum of the output signal to calculate the dependence of the THD on the duration of the «dead time». In [6], the authors proposed a method for calculating the THD, dividing the width-modulated signal at the output of the amplifier into three components: a symmetrical rectangular signal with a fill factor of $0.5 p_{\mathrm{c}}(t)$; a sequence of pulses, the duration of which depends on the modulating signal, $p_{\mathrm{s}}(t)$, and the error signal $e(t)$ caused by «dead time». The output voltage of the amplifier is calculated by the formula given in [6]:

$$
v_{0}(t)=p_{c}(t)+p_{s}(t)-e(t) .
$$

Accordingly, the spectrum of the output signal is the sum of the spectra of the components. The full spectrum at the output of the amplifier and the amplitude of the individual harmonics $C_{n}$ is calculated by the following formulas [6]:

$$
V_{o, p}(f)=P_{c, p}(f)+P_{s, p}(f)-E_{p}(f),
$$

where

$$
\begin{gathered}
P_{c, p}(f)=j T \sin c\left(\frac{T}{2} f\right) \sin \left(\pi \frac{T}{2} f\right) \frac{\sin (\pi M T f)}{\sin (\pi T f)}, \\
P_{s, p}(f)=\sum_{k=0}^{M-1} \frac{1}{j \pi f}\left(e^{-j 2 \pi(k+1 / 2) T f}-e^{-j 2 \pi\left(k T+\tau_{k}\right) f}\right) ; \\
E_{p}(f)=\left(\sum_{k=0}^{\frac{M}{2}-1} e^{-j 2 \pi f(k T)}-\sum_{k=\frac{M}{2}}^{M-1} e^{-j 2 \pi f\left(k T+\tau_{k}\right)}\right) \times \\
\times 2 \Delta \frac{\sin (\Delta f)}{\Delta f} e^{-j \pi \Delta f} ; \\
\tau_{k}=\frac{T}{2}\left[1+\frac{M}{\pi} \cot \left(\theta_{k}\right)+\frac{M}{2 m \pi^{2}} \csc \theta_{k}(-2 M+\right. \\
\left.\left.+\sqrt{4 M^{2}+6 m_{0}^{2} \pi^{2}-2 m \pi\left[4 M \cos \theta_{k}+m \pi \cos \left(2 \theta_{k}\right]\right.}\right)\right]
\end{gathered}
$$




$$
\begin{gathered}
\theta_{k}=2 \pi(k+0,5) / M ; \\
C_{n}=\left.\frac{1}{M T} V_{o, p}(f)\right|_{f=\frac{n}{M T}},
\end{gathered}
$$

where $M=f_{\mathrm{c}} / f_{\mathrm{s}}$ is the ratio of the switching frequency $f_{\mathrm{c}}$ to the signal frequency $f_{\mathrm{s}}, T=1 / f_{\mathrm{c}}$ is the switching period, $\Delta$ is the duration of the «dead time» relative to the period $T$, $m$ is the modulation depth, $k$ is the number of the switching interval.

THD, which was used for comparison with the results of computer simulation, was calculated in $\%$ by the formula given below [6]:

$$
T H D=\frac{100}{\left|C_{1}\right|^{2}} \sum_{n=2}^{6}\left|C_{n}\right|^{2},
$$

where $C_{1}$ is the amplitude of the first harmonic of the signal.

Estimation of the influence of load inductance on THD values caused by «dead time». The calculation of the THD at the output of the amplifier is performed by the formula

$$
T H D=\frac{\sqrt{A_{2}^{2}+A_{3}^{2}+A_{4}^{2}+\ldots+A_{k}^{2}}}{A_{1}},
$$

where $A_{1}, A_{2}, \ldots A_{k}$ are the harmonics of the output signal.

To calculate the CGS, the first 7 harmonics were taken, by analogy with formula (9).

The computer model shown in Fig. 1, contains a pulse-width modulator U1, which increases the nonlinear distortion of the output signal. In order to estimate the contribution of nonlinear distortions of the modulator to the overall level, the THD at its output is calculated for each of the operating frequencies of the amplifier. The results of the calculations are given in Table 2 .

Table 2

THD at the output of the PWM element for different frequencies of transformation

\begin{tabular}{|c|c|}
\hline Parameters & THD, $\%$ \\
\hline$f_{\mathrm{c}}=1 \mathrm{kHz}$ & 0.033 \\
\hline$f_{\mathrm{c}}=2 \mathrm{kHz}$ & 0.05 \\
\hline$f_{\mathrm{c}}=100 \mathrm{kHz}$ & 0.012 \\
\hline$f_{\mathrm{c}}=400 \mathrm{kHz}$ & 0.01 \\
\hline
\end{tabular}

As can be seen from Table 2, THD values for different conversion frequencies vary in the range of $0.01-0.05 \%$ and will be taken into account in further comparison of results. It should be noted that the feature of the PWM element U1 is the reduction of the THD at high conversion frequencies.

Figure 3 shows the results of the calculation of the THD at the output of the amplifier depending on the value of the inductance of the output choke. The simulation was performed for a signal frequency of $50 \mathrm{~Hz}$ and conversion frequencies of $1 \mathrm{kHz}, 2 \mathrm{kHz}, 100 \mathrm{kHz}$ and $400 \mathrm{kHz}$. The duration of «dead time» during simulation was $10 \%$. The inductance values varied in the range from $47 \mu \mathrm{H}$ to $22 \mathrm{mH}$. The value of the load resistor remained unchanged $-8 \Omega$.

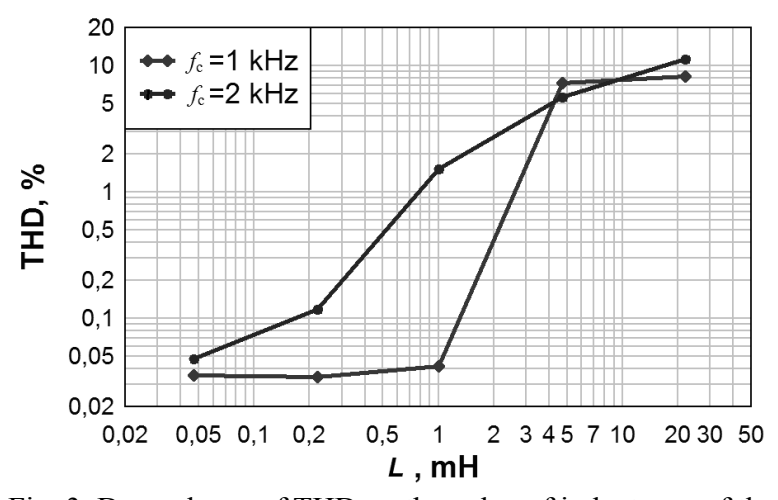

Fig. 3. Dependence of THD on the value of inductance of the output choke

As can be seen from Fig. 3, with increasing load inductance, the THD increases. At a maximum value of inductance of $22 \mathrm{mH}$, the maximum THD is observed both for the conversion frequency of $1 \mathrm{kHz}$ and for the frequency of $2 \mathrm{kHz}$. Although the dependence for the frequency of $2 \mathrm{kHz}$ is more gentle.

Similar dependencies are observed when amplifying the sound signal with conversion frequencies of $100 \mathrm{kHz}$ and $400 \mathrm{kHz}$ (Fig. 4). As the inductance of the choke increases, the distortions caused by the «dead time» increase. Although for a frequency of $400 \mathrm{kHz}$ after a certain maximum there is a decrease in THD.

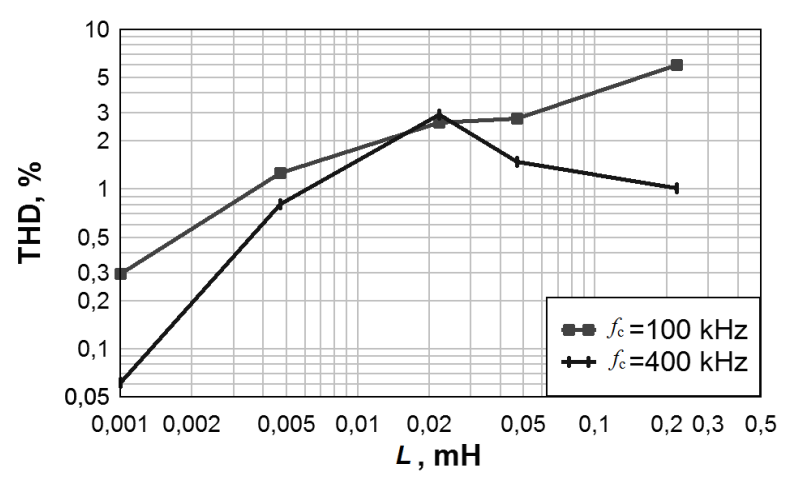

Fig. 4. Dependence of THD on the value of the inductance of the output choke for the conversion frequencies of 100 and $400 \mathrm{kHz}$

Thus, it can be argued that the value of the inductance at the output of the amplifier affects the level of nonlinear distortion caused by «dead time», changing the ratio of intervals when the current sign does not change (input and output signals do not match in duration) and changes (PWM signal pulse duration at the input and at the output coincides). Reducing the load circuit time constant also reduces the THD of the output signal, which was noted in [5].

Additional factors that affect the THD at low supply voltages may be the voltage jumps on the diodes of the transistors in the mode when the current sign does not change during the switching period. The fact that both transistors are closed and the choke current flows twice through the diode of one of the transistors can increase the THD. The voltage drop across the diode $U_{d}$ is added to the supply voltage (Fig. 5,a) and changes the amplitude of the current $I_{0}(t)$ through the choke. Reducing the duration of «dead time» reduces the impact of output voltage $U_{0}(t)$ 
jumps on the THD. The effect of voltage drop across diodes on THD requires further research.

Figure $5, b$ shows the shape of the output pulses for a switching frequency of $400 \mathrm{kHz}$ (solid line), when the sign of the output current $I_{0}(t)$ does not change. When the input voltage $U_{i n}(t)$ changes to zero, there is a process of delaying the output voltage drop $U_{0}(t)$ due to the charge of the output capacitance of the transistor in the interval of «dead time». In the next «dead time» interval, the current flows through the diode and creates a delay in switching the output voltage compared to the input signal (line with triangles).

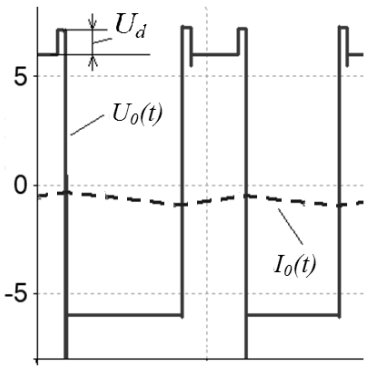

$a$

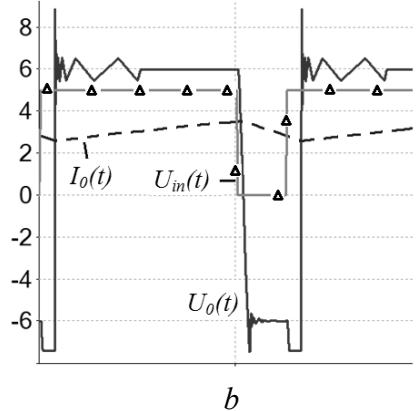

b
Fig. 5. Output voltage jumps due to voltage drop across diodes (a) and the effect of the output capacitance of the transistor on the shape of the output pulses $(b)$

Comparison of mathematical and computer simulation results. Next, a comparison of the THD calculated according to the formulas above with the THD obtained by simulation for different values of inductance of the choke is carried out. Figure 6 shows the dependencies of the THD on the duration of the «dead time» calculated by formula (1) and modelled for the following parameters of the amplifier: signal frequency $f_{\mathrm{s}}=50 \mathrm{~Hz}$, conversion frequencies $f_{\mathrm{c}}=1 \mathrm{kHz}, 2 \mathrm{kHz}$, modulation depth $m=0.6$.

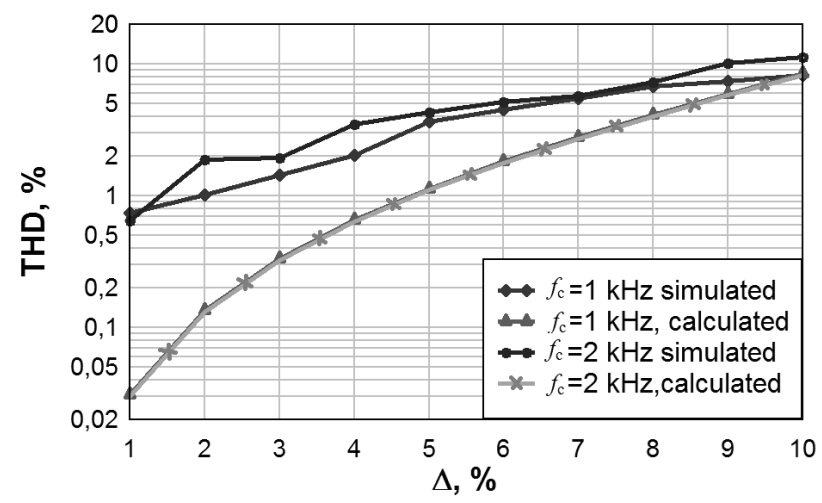

Fig. 6. Dependence of THD on the value of $\Delta$ for the inductance of the choke $22 \mathrm{mH}$

The curves show that the dependence of THD on the duration of «dead time» as a result of modelling exceeds the calculations by formula (1) by $0.6 \%-4 \%$. The high values of the THD can be explained by the fact that the inductance of the output choke provides the current sign constant throughout almost the entire period of the signal, which is amplified, so the THD increases with increasing $\Delta$.
Figure 7 shows the curves of the THD dependence on the duration of the «dead time» for the case when the output inductance provides a change in the sign of the current twice for the switching period. In this case, the THD does not change significantly when changing $\Delta$ from $1 \%$ to $10 \%$, which differs from the values of THD at the output of the amplifier, calculated by formula (9).

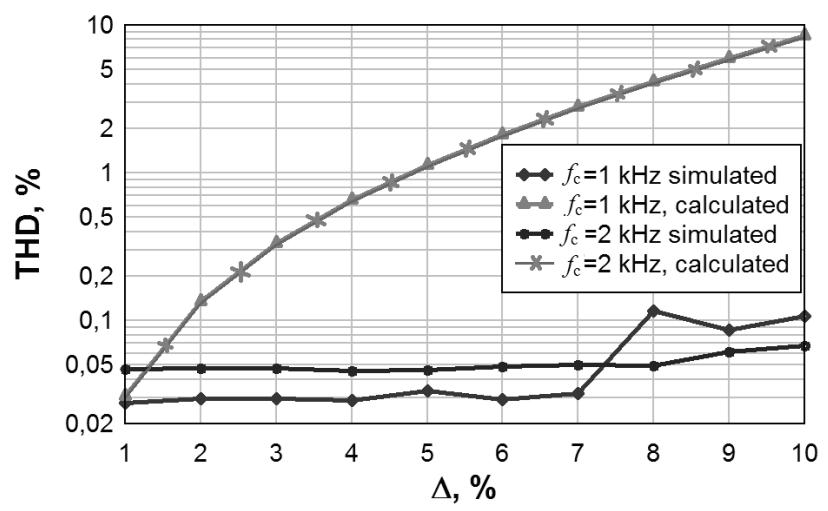

Fig. 7. Dependence of THD on the value of $\Delta$ for the inductance of the choke $470 \mu \mathrm{H}$

The greatest interest is the effect of load inductance on the THD at switching frequencies from $100 \mathrm{kHz}$, on which the sound amplifiers of class D operate. The dependencies of the THD on the duration of the «dead time» are shown in Fig. 8 for an inductance of $47 \mu \mathrm{H}$. The use of $\mathrm{GaN}$ transistors in this case provides a switching frequency of $400 \mathrm{kHz}$ and higher.

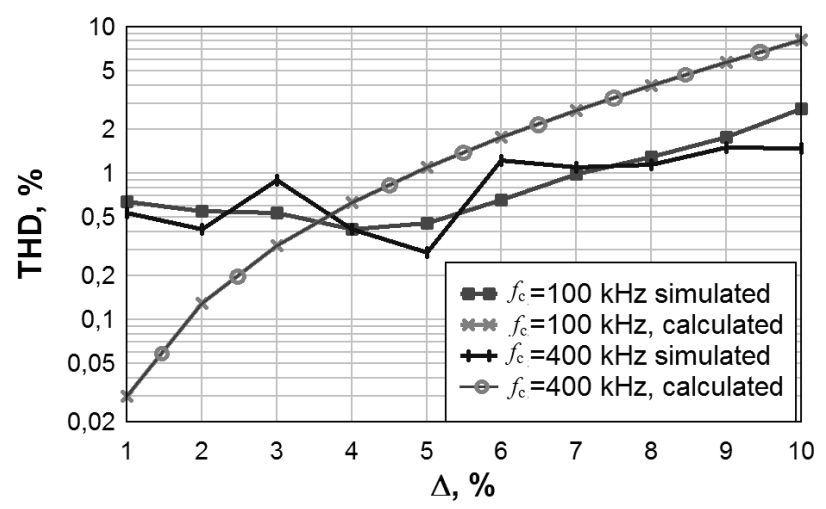

Fig. 8. Dependence of THD on the value of $\Delta$ for the inductance of the choke $47 \mu \mathrm{H}$

If for the switching frequency of $100 \mathrm{kHz}$ there is an increase in THD with an increase of $\Delta$ from $0.5 \%$ to $3 \%$, then for the switching frequency of $400 \mathrm{kHz}$ the level of distortion at values of $\Delta>6 \%$ practically does not increase. Although the effect of inductance of $47 \mu \mathrm{H}$ should be greater at a frequency of $100 \mathrm{kHz}$. This result can be explained by the recharging of the output capacitance of the transistors, which compensates for voltage jumps (see Fig. 3,b).

Thus, the dependence of THD on the duration of «dead time» as a result of modelling differs from the calculated one.

\section{Conclusions.}

The paper evaluates the influence of the load inductance at the output of the class D amplifier on the 
level of nonlinear distortions caused by «dead time». As a result, it was found that reducing the value of inductance within certain limits reduces the THD. This is due to the reduction of the number of errors between the input and output signal, which occur at a constant sign of the inductance current during the output pulse. When the inductance decreases, the number of intervals in which there is no error increases. Thus, the change in the value of the load inductance leads to a change in the ratio of the intervals with and without error, and hence to a change in the THD.

At high conversion frequencies, the voltage jumps caused by the current through the built-in diodes during the «dead time» are partially compensated by recharging the output capacitance of the transistors, which also reduces nonlinear distortions.

The next stage of research is to create a mathematical model of the PWM signal at the output of the class D amplifier, which takes into account the effect of load inductance on the THD, and its experimental verification.

Conflict of interest. The authors declare that they have no conflicts of interest.

\section{REFERENCES}

1. Koeslag F., du T. Mouton H., Beukes H. J., Midya P. A detailed analysis of the effect of dead time on harmonic distortion in a class D audio amplifier. AFRICON 2007, 2007, pp. 1-7. doi: https://doi.org/10.1109/afrcon.2007.4401640.

2. Wu C. M., Lau Wing-Hong, Shu-Hung Chung H. Analytical technique for calculating the output harmonics of an H-bridge inverter with dead time. IEEE Transactions on Circuits and Systems I: Fundamental Theory and Applications, 1999, vol. 46, no. 5, pp. 617-627. doi: https://doi.org/10.1109/81.762927.

3. Li C., Gu Y., Li W., He X., Dong Z., Chen G., Ma C., Zhang L. Analysis and compensation of dead-time effect considering parasitic capacitance and ripple current. 2015 IEEE Applied Power Electronics Conference and Exposition (APEC), 2015, pp. 1501-1506. doi: https://doi.org/10.1109/apec.2015.7104546.

4. Mauerer M., Tüysüz A., Kolar J. W. Distortion analysis of low-THD/high-bandwidth $\mathrm{GaN} / \mathrm{SiC}$ class-D amplifier power stages. 2015 IEEE Energy Conversion Congress and Exposition (ECCE), 2015, pp. 2563-2571. doi: https://doi.org/10.1109/ecce.2015.7310020.
5. Mauerer M., Kolar J. W. Distortion minimization for ultralow THD class-D power amplifiers. CPSS Transactions on Power Electronics and Applications, 2018, vol. 3, no. 4, pp. 324-338. doi: https://doi.org/10.24295/cpsstpea.2018.00032.

6. Chierchie F., Paolini E. E. Analytical and numerical analysis of dead-time distortion in power inverters. 2010 Argentine School of Micro-Nanoelectronics, Technology and Applications (EAMTA), 2010, pp. 6-11. Available at: https://ieeexplore.ieee.org/document/5606373 (accessed 22 June 2020)

7. Chierchie F., Paolini E. E. Quasi-analytical spectrum of PWM signals with dead-time for multiple sinusoidal input. 2011 IEEE International Symposium of Circuits and Systems (ISCAS), 2011, pp. 1033-1036. doi: https://doi.org/10.1109/iscas.2011.5937745.

8. Chierchie F., Stefanazzi L., Paolini E. E., Oliva A. R. Frequency analysis of PWM inverters with dead-time for arbitrary modulating signals. IEEE Transactions on Power Electronics, 2014, vol. 29, no. 6, pp. 2850-2860. doi: https://doi.org/10.1109/tpel.2013.2276098.

9. Onikienko Y.O., Pilinsky V.V., Popovych P.V., Lazebnyi V.S., Smolenska O.I., Baran V.S. Modelling of operation modes and electromagnetic interferences of $\mathrm{GaN}$-transistor converters. Electrical Engineering \& Electromechanics, 2020, no. 3, pp. 37 42. doi: https://doi.org/10.20998/2074-272X.2020.3.06.

10. Gedz O., Lazebnyi V., Onikienko Y., Vlasjuk A. EMI simulation of $\mathrm{GaN}$ power stage for audio class D amplifiers. 2018 14th International Conference on Advanced Trends in Radioelecrtronics, Telecommunications and Computer Engineering (TCSET), 2018, pp. 204-207. doi: https://doi.org/10.1109/tcset.2018.8336187.

Received 03.04.2021

Accepted 10.05.2021

Published 25.06.2021

S.A. Naida ${ }^{1}$, Doctor of Technical Science, Professor,

Y.O. Onykienko ${ }^{1}$, PhD, Associate Professor,

O.I. Drozdenko ${ }^{1}, P h D$, Associate Professor,

O.I. Smolenska ${ }^{1}$, Postgraduate Student,

V.S. Baran ${ }^{1}$, Postgraduate Student,

N.O. Iakunina ${ }^{1}, P h D$, Associate Professor,

${ }^{1}$ National Technical University of Ukraine «Igor Sikorsky Kyiv Polytechnic Institute»,

37, Prospect Peremohy, Kyiv-56, 03056, Ukraine,

e-mail: yurionik@gmail.com (Corresponding author)

\section{How to cite this article:}

Naida S.A., Onykienko Y.O., Drozdenko O.I., Smolenska O.I., Baran V.S., Iakunina N.O. Analysis of the influence of load inductance on nonlinear distortions of a class D amplifier caused by «dead time». Electrical Engineering \& Electromechanics, 2021, no. 3, pp. 32-37. doi: https://doi.org/10.20998/2074-272X.2021.3.05. 